\title{
Comparison of Plasma Levels of Tryptophan Metabolites between Healthy People and Patients of Bipolar Depression at Various Age and Gender
}

\author{
Hiroi Tomioka $^{1,2}$, Junichi Masuda ${ }^{3}$, Akikazu Takada ${ }^{4}$, Akira Iwanami $^{1}$ \\ ${ }^{1}$ Department of Psychiatry, Showa University School of Medicine, Tokyo, Japan; ${ }^{2}$ Department of Psychiatry, Showa \\ University Northern Yokohama Hospital, Yokohama, Japan; ${ }^{3}$ Global Application Development Center, Shimadzu \\ Corporation, Kanagawa-ken, Japan; ${ }^{4}$ International Projects on Food and Health (NPO), Tokyo, Japan
}

Correspondence to: Akikazu Takada, takadaa@mwd.biglobe.ne.jp

Keywords: Depression, Monopolar Depression, Bipolar Depression, Tryptophan, Serotonin, 5-Hydroxyindole Acetic Acid, Kynurenine, SSRI (Selective Serotonin Reuptake Inhibitor), SNRI (Serotonin Norepinephrine Reuptake Inhibitor), Anxiolytic, Antipsychotic

Received: May 20, $2020 \quad$ Accepted: June 20, $2020 \quad$ Published: June 23, 2020

Copyright $\odot 2020$ by author(s) and Scientific Research Publishing Inc.

This work is licensed under the Creative Commons Attribution International License (CC BY 4.0).

http://creativecommons.org/licenses/by/4.0/

\section{(c) (i) Open Access}

\section{ABSTRACT}

Background: It is not well analyzed whether there are differences in plasma levels of tryptophan (TRP) metabolites between healthy control people (HC) and patients of type II bipolar depression (BDII). Methods: Ultra high-speed liquid chromatography/mass spectrometry has been used for the simultaneous determination of plasma levels of tryptophan metabolites in depressive patients. Results: Plasma levels of TRP are not different between HC and patients of BDII. Serotonin (5-HT) levels are higher in BDII than HC. Plasma levels of 5-HIAA of HC are higher than those of old women of BDII, but lower in young women of BDII. Plasma levels of kynurenine (KYN) of HC are not different from those of patients of BDII. Conclusion: Plasma levels of 5-HT are higher in patients of BDII than those of HC, which may suggest that use of drugs inhibiting the 5-HT transportation and lower transporter biding may increase plasma levels of 5-HT in patients of BD.

\section{INTRODUCTION}

At the end of $19^{\text {th }}$ century, Emil Kraepelin proposed a broad concept called "Manic-Depression Insanity" which included current day bipolar disorder (BD) and major depressive disorder (MDD) [1, 2]. In the mid 20 century, the current concept of bipolar disorder emerged. In the 1970s, a subgroup of BD was recognized, BDII, which was characterized by a prominent recurrences of major depressive episodes. BDI was characterized by recurrences of manic and depressive episode [3]. 
It is well recognized that the differential diagnosis of MMD from BDI is very difficult when periods of hypomania were very short.

Recently, we succeeded in the simultaneous measurements of TRP metabolites including 5-HT, 5-HIAA or KYN by using an ultra high speed liquid chromatography/mass spectroscopy (LC/MS) [4-7].

We reported that age and gender differences of plasma levels of TRP metabolites disappeared in patients of major monopolar depression although some metabolites levels were in patients of some age and gender in bipolar depression [8].

By using the method, we reported that there are no significant differences between plasma levels of TRP between HC and MMD. Plasma levels of TRP of are higher in young men, young women, old men, and old women in this order. Serotonin (5-HT) levels are higher in MMD than HC. Plasma levels of 5-HIAA of HC are also higher than those of patients of MMD. Plasma levels of kynurenine (KYN) of healthy old men and old women are higher than those of young men and old women. Plasma levels of KYN are higher in old women and young men of MMD than those of HC [9].

In the present research, we compared plasma levels of TRP, 5-HT, 5-HIAA, and KYN of patients of $\mathrm{BD}$ with HC.

\section{STATSITICS}

Statistical significance of the differences between groups was calculated according to one-way ANOVA. When ANOVA indicated a significant difference $(\mathrm{P}<0.05)$, the mean values of the treatment were compared using Tukey's least significant difference test at $\mathrm{P}<0.05$.

The statistical comparison between groups is analyzed by the two way ANOVA.

Statistical significance is expressed as followed. ${ }^{*} ; \mathrm{p}<0.05,{ }^{* *} ; \mathrm{p}<0.001$.

\section{METHODS}

\subsection{Patients}

Outpatients of depression were recruited in this study. Patients were diagnosed using the criteria of Diagnostic and Statistical Manual of Mental Disorders, the 5th edition (DSM-5, American Psychiatric Association 2013) [10]. Fasting blood samples were taken early in the morning. Their severity of depression was checked by CGI-S [11], SDS [12], and HDR-S [13]. The history of prescriptions of drugs such as antidepressants, anxyolitics, mood stabilizers and other drugs were asked.

Sample numbers are 55 (male; 15, and female 40, and average age; $45.4 \pm 11.9$ ). The number of MDD is 36 and BD is 19. Further characteristics of patients are described below. Outpatients who showed symptoms of depression were recruited in the studies at the Department of Psychiatry of Showa University Northern Yokohama Hospital. Patients were required to have had no lifetime history of psychosis, personality disorder, or drug or alcohol misuse. We also excluded patients who had organic problems of the brains. This study was carried out from 2016 to 2019. All patients gave their consent in a written form after receiving comprehensive information on the study protocol.

\subsection{Healthy Volunteers}

We asked volunteers to provide blood early morning before breakfast. The backgrounds of these people were reported elsewhere [9].

\subsection{Measurements of TRP Metabolites}

Plasma factors were measured after plasma was separated from blood $\left(3000 \mathrm{rpm} / \mathrm{min}\right.$. at $\left.4^{\circ} \mathrm{C}\right)$. Ethylenediaminetetraacetic acid (EDTA) was used as an anticoagulant.

The simultaneous measurements of TRP metabolites in plasma were performed by using an ultrahigh-speed liquid chromatography/spectrometry. Detailed methodology was described elsewhere [4-7]. 


\section{RESULTS}

\subsection{Comparison of Trp Metabolites between HC and Patients of BD}

Table 1 shows differences of plasma levels of TRP, 5-HT, 5-HIAA < and KYN between HC and patients of BD. Detailed explanations will be shown together with Figures.

\subsection{Comparison of Plasma Levels of TRP of HC and Patients of BD}

There was significant effect of sample name $(\mathrm{F}(3,84)=10.288, \mathrm{p}<0.01)$, but there was no significant effect of diagnosis $(\mathrm{F}(1,84)=0.530, \mathrm{p}=0.468)$, and there was no significant interaction between diagnosis and sample name $(\mathrm{F}(3,84)=1.357, \mathrm{p}=0.261)$. Figure 1 shows plasma levels of TRP metabolite in $\mathrm{HC}$ and patients of BD.

Tukey's post hoc test showed that TRP level of old women were lower than that of young men $(\mathrm{p}<$ $0.01)$, young women $(\mathrm{p}<0.01)$, and old men $(\mathrm{p}<0.01)$.

There was no significant difference between plasma levels of TRP between HC and patients of BD.

\subsection{Comparison of Plasma Levels of 5-HT of HC and Patients of BD}

There was significant effect of diagnosis $(\mathrm{F}(1,73)=31.113, \mathrm{p}<0.01)$, but there was no significant effect of sample name $(F(3,73)=2.252, \mathrm{p}=0.090)$, and there was no significant interaction between diagnosis and sample name $(\mathrm{F}(3,73)=1.767, \mathrm{p}=0.161)$.

Figure 2 shows that plasma levels of 5-HT were higher in $\mathrm{HC}$ than patients of BD.

\subsection{Comparison of Plasma Levels of KYN of HC and Patients of BD}

There was significant effect of sample name $(\mathrm{F}(3,84)=9.700, \mathrm{p}<0.01)$, but there was no significant effect of diagnosis $(\mathrm{F}(1,84)=2.500, \mathrm{p}=0.118)$, and there was no significant interaction between diagnosis and sample name $(\mathrm{F}(3,84)=1.739, \mathrm{p}=0.165)$.

Tukey's post hoc test showed that KYN level of young men was lower than that of young women ( $<<$ $0.01)$ and old men $(\mathrm{p}<0.01)$.

Figure 3 shows that KYN level of old women were lower than old men $(\mathrm{p}<0.01)$ and young women $(\mathrm{p}<0.01)$.

\subsection{Comparison of Plasma Levels of 5-HIAA between HC and Patients of BD}

Figure 4 shows that in HC, 5-HIAA level of young men were lower than young ${ }^{\star \star}$ women $(\mathrm{p}<0.01)$ and ${ }^{* *}$ old men $(\mathrm{p}<0.01)$. And 5-HIAA level of ${ }^{\star \star}$ old women were lower than ${ }^{\star \star}$ young women $(\mathrm{p}<0.01)$ and ${ }^{\star *}$ old men $(\mathrm{p}<0.01)$.

In $\mathrm{BD}, 5$-HIAA level of old women were higher than ${ }^{\star}$ young men $(\mathrm{p}<0.01),{ }^{*}$ young women $(\mathrm{p}<$ $0.01)$ and ${ }^{*}$ old men $(\mathrm{p}<0.01)$.

In ${ }^{* *}$ young women, 5-HIAA level of HC were higher than $\mathrm{BD}(\mathrm{p}<0.01)$.

In ${ }^{* *}$ old women, 5-HIAA level of BD were higher than HC $(\mathrm{p}<0.01)$.

\section{DISCUSSION}

Type II $\mathrm{BD}$ is a common and recurrent psychiatric illness. Initially, type II BD was considered a benign form of type I BD, but type II $\mathrm{BD}$ is now considered to be as disabling as type I BD [14] because patients of type II BD show multiple and more protracted depressive episodes [15]. Patients of type II BD show more chronic form of depression compared with patients of type I BD. They show less chances of returning to premorbid levels of life between episodes [16].

Pharmacological treatments of type II are reviewed [17], so we do not further discuss merits and demerits of these drugs here. Since 5-HT reuptake inhibitors such as SSRI (selective serotonin reuptake inhibitor) or SNRI (serotonin noradrenalin reuptake inhibitor) prevent uptake of 5-HT into platelets, thus influencing plasma levels of 5-HT, we mention about effects of such drugs. 


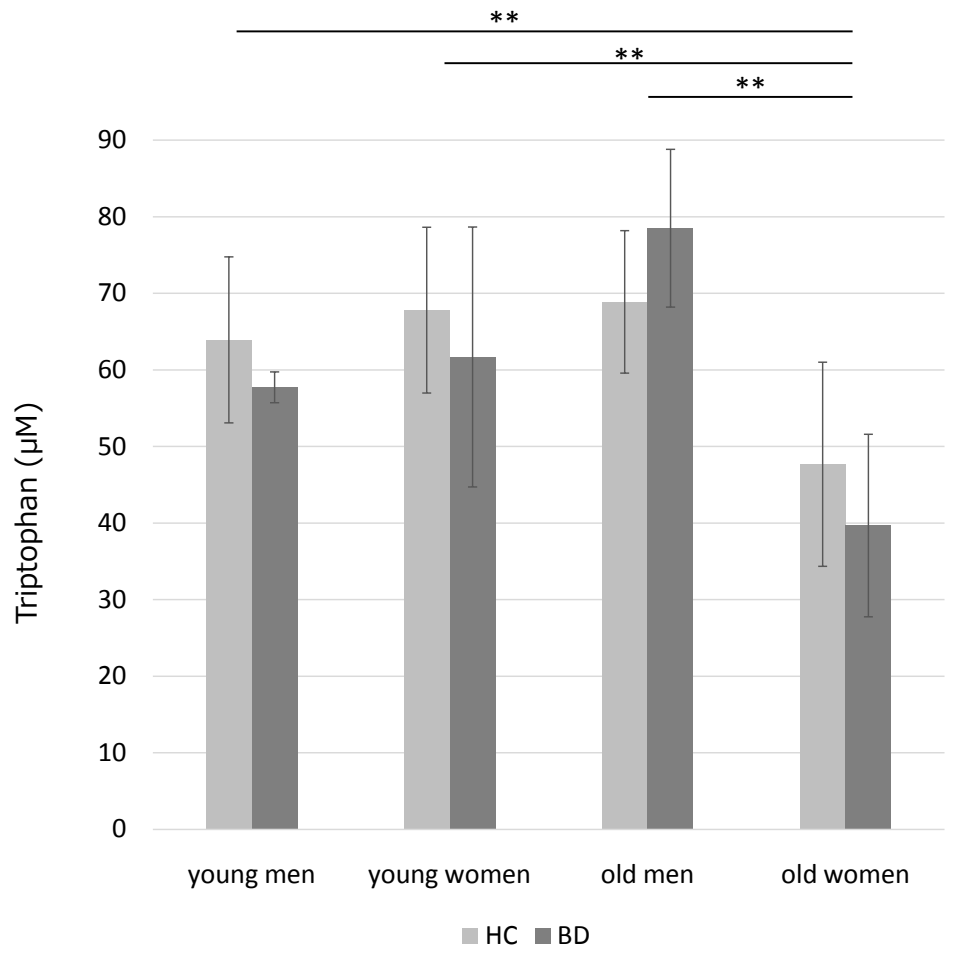

Two-way ANOVA with diagnosis (HC and BD) and sample name (young and old men and women) was used for evaluating statistical significance.

Figure 1. Plasma levels of TRP of HC and patients of BD. ${ }^{* *}$ Sample name, old women $<$ young men, young women and old men.

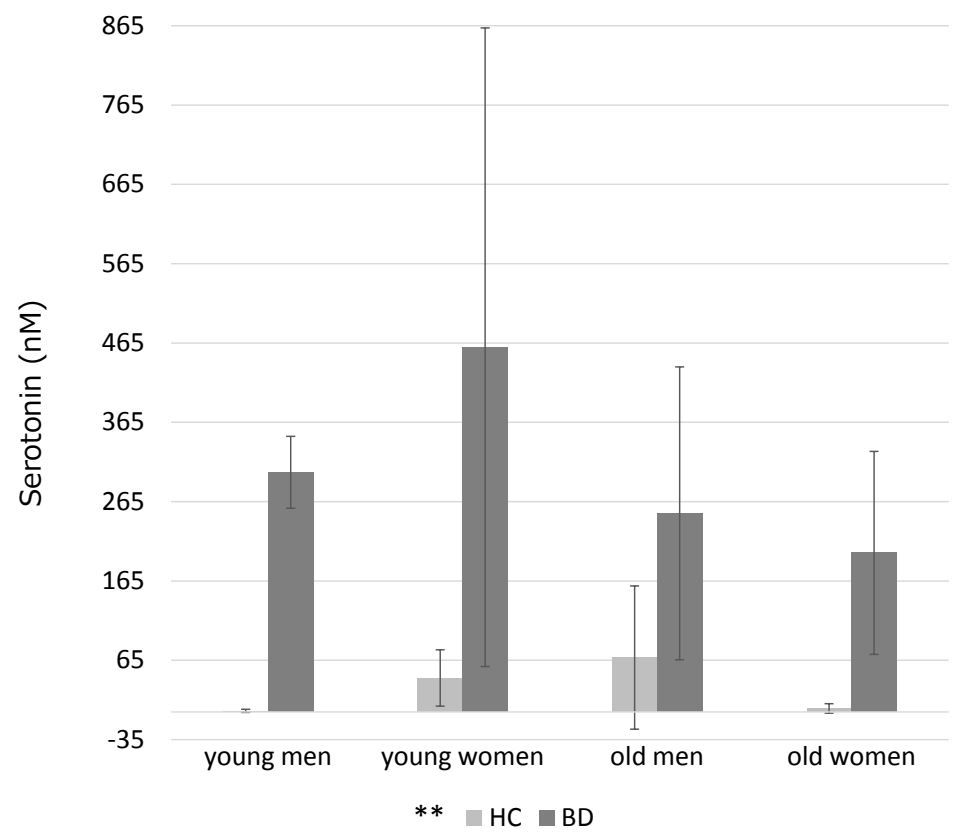

Two-way ANOVA with diagnosis( $\mathrm{HC}$ and $\mathrm{BD}$ ) and sample name (young and old men and women) was used for evaluating statistical significance.

Figure 2. Plasma levels of 5-HT of HC and patients of BD. ** Diagnosis, $\mathrm{HC}(18.259 \pm 43.138 \mathrm{nM})<\mathrm{BD}(373.679 \pm 329.281 \mathrm{nM})$. 


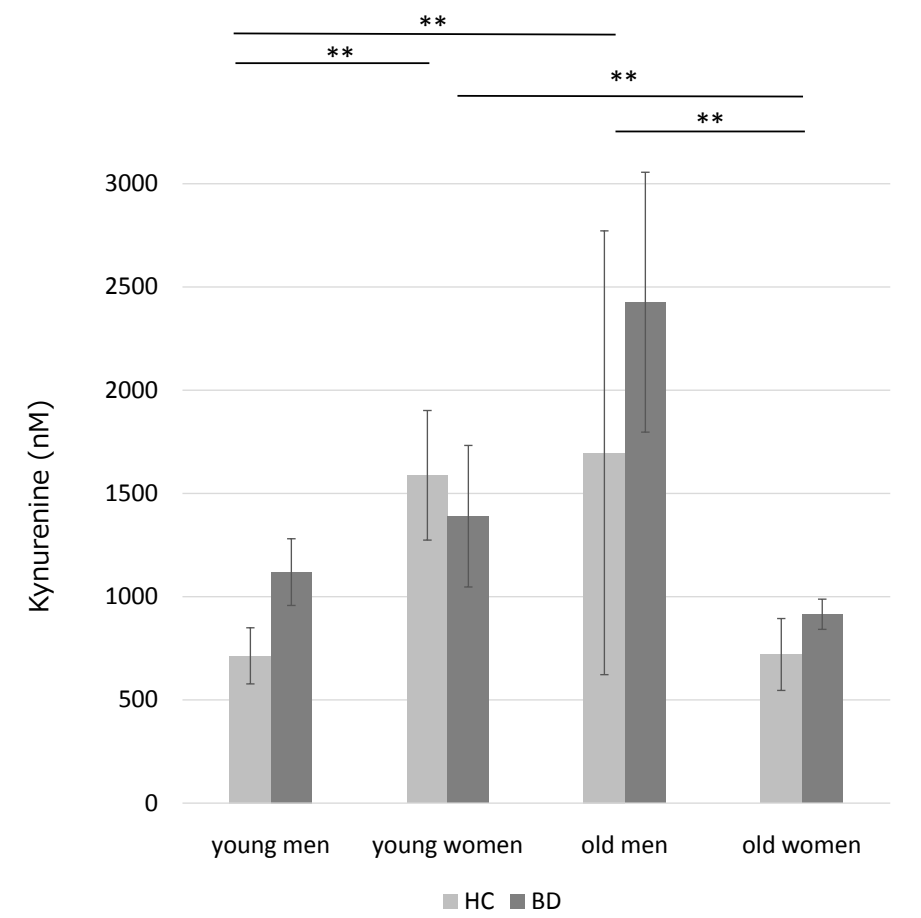

Two-way ANOVA with diagnosis(HC and BD) and sample name (young and old men and women) was used for evaluating statistical significance.

Figure 3. Plasma levels of KYN of HC and patients of BD. ** Sample name, young men $<$ young women and old men, old women $<$ old men and young women.

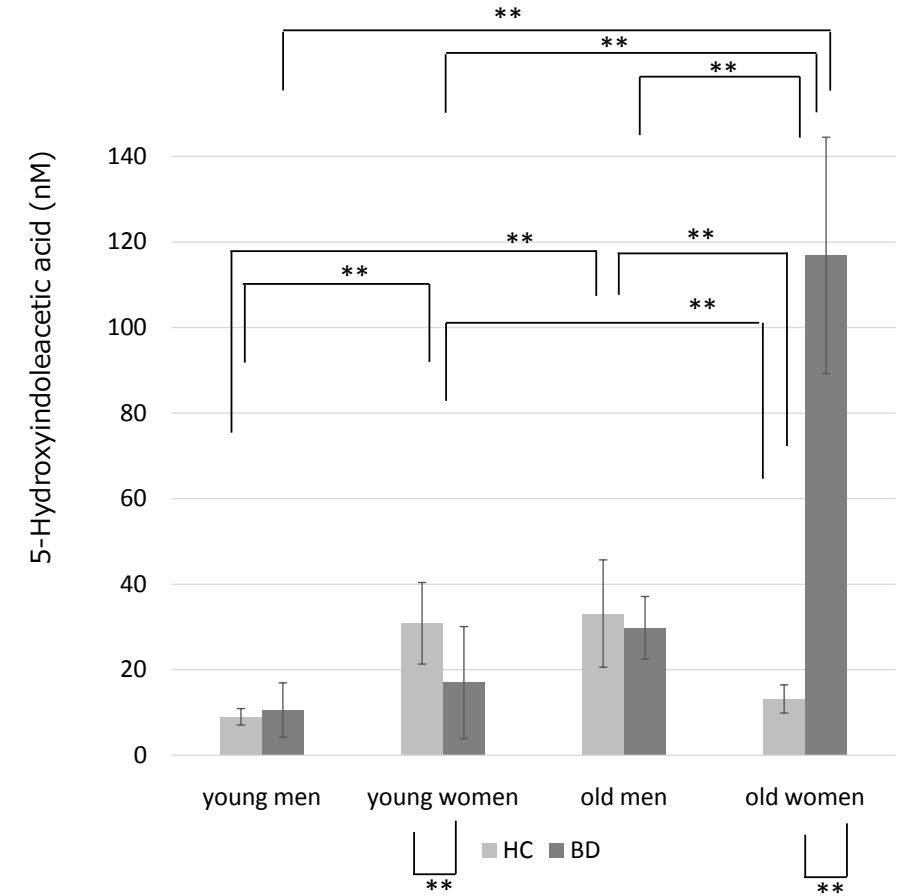

Two-way ANOVA with diagnosis(HC and BD) and sample name (young and old men and women) was used for evaluating statistical significance.

Figure 4. Plasma levels of 5-HIAA of HC and patients of BD. Sample name, $F(3,84)=54.060, p<$ 0.01; Diagnosis, $\mathrm{F}(1,84)=59.307, \mathrm{p}<0.01$; Sample name ${ }^{*}$ diagnosis, $\mathrm{F}(3,84)=82.635, \mathrm{p}<0.01$. 
Table 1. Comparison of TRP, 5-HT, 5-HIAA and KYN between HC and patients of BD.

\begin{tabular}{|c|c|c|c|c|c|c|c|c|c|}
\hline \multirow{2}{*}{$\begin{array}{c}\text { Diagnosis } \\
\text { Sample name }\end{array}$} & \multicolumn{4}{|c|}{$\begin{array}{c}\mathrm{HC} \\
\mathrm{n}=38\end{array}$} & \multicolumn{4}{|c|}{$\begin{array}{c}\mathrm{BD} \\
\mathrm{n}=17\end{array}$} & \multirow[b]{2}{*}{$\begin{array}{l}\text { significant } \\
\text { differences }\end{array}$} \\
\hline & $\begin{array}{l}\text { young } \\
\text { men } \\
\mathrm{n}=25 \\
\mathrm{a}\end{array}$ & $\begin{array}{c}\text { young } \\
\text { women } \\
\mathrm{n}=10 \\
\mathrm{~b}\end{array}$ & $\begin{array}{l}\text { old men } \\
\mathrm{n}=20 \\
\mathrm{C}\end{array}$ & $\begin{array}{c}\text { old } \\
\text { women } \\
\mathrm{n}=20 \\
\mathrm{~d}\end{array}$ & $\begin{array}{l}\text { young } \\
\text { men } \\
\mathrm{n}=2 \\
\mathrm{a}\end{array}$ & $\begin{array}{c}\text { young } \\
\text { women } \\
\mathrm{n}=10 \\
\mathrm{~b}\end{array}$ & $\begin{array}{c}\text { old men } \\
\mathrm{n}=3 \\
\mathrm{c}\end{array}$ & $\begin{array}{c}\text { old } \\
\text { women } \\
\mathrm{n}=2 \\
\mathrm{~d}\end{array}$ & \\
\hline $\begin{array}{l}\text { Tryptophan } \\
(\mu \mathrm{M})\end{array}$ & $\begin{array}{c}63.92 \pm \\
10.84\end{array}$ & $\begin{array}{c}67.79 \pm \\
9.30\end{array}$ & $\begin{array}{c}68.89 \pm \\
13.32\end{array}$ & $\begin{array}{c}47.68 \pm \\
7.19\end{array}$ & $\begin{array}{c}57.71 \pm \\
2.006\end{array}$ & $\begin{array}{c}61.68 \pm \\
16.96\end{array}$ & $\begin{array}{c}78.50 \pm \\
10.30\end{array}$ & $\begin{array}{c}39.66 \pm \\
11.91\end{array}$ & ${ }^{\star} 1$ \\
\hline $\begin{array}{l}\text { Serotonin } \\
\quad(\mathrm{nM})\end{array}$ & $\begin{array}{c}1.29 \pm \\
1.97\end{array}$ & $\begin{array}{c}42.90 \pm \\
35.49\end{array}$ & $\begin{array}{c}68.61 \pm \\
90.31\end{array}$ & $\begin{array}{c}4.49 \pm \\
6.03\end{array}$ & $\begin{array}{c}302.0 \pm \\
45.28\end{array}$ & $\begin{array}{c}459.7 \pm \\
402.5\end{array}$ & $\begin{array}{c}250.3 \pm \\
184.6\end{array}$ & $\begin{array}{c}200.5 \pm \\
128.0\end{array}$ & ${ }^{*} 2$ \\
\hline $\begin{array}{l}\text { Kynurenine } \\
(\mathrm{nM})\end{array}$ & $\begin{array}{c}713.18 \pm \\
136.02\end{array}$ & $\begin{array}{c}1588.09 \pm \\
313.52\end{array}$ & $\begin{array}{c}1696.82 \pm \\
1074.65\end{array}$ & $\begin{array}{c}719.94 \pm \\
173.87\end{array}$ & $\begin{array}{c}1119.0 \pm \\
161.08\end{array}$ & $\begin{array}{c}1389.8 \pm \\
342.36\end{array}$ & $\begin{array}{c}2426.2 \pm \\
628.86\end{array}$ & $\begin{array}{c}914.89 \pm \\
73.22\end{array}$ & $* 3$ \\
\hline $\begin{array}{l}\text { 5-Hydroxyindole } \\
\text { acetic acid } \\
(\mathrm{nM})\end{array}$ & $\begin{array}{c}9.00 \pm \\
1.92\end{array}$ & $\begin{array}{c}30.87 \pm \\
9.55\end{array}$ & $\begin{array}{c}33.15 \pm \\
12.57\end{array}$ & $\begin{array}{c}13.17 \pm \\
3.30\end{array}$ & $\begin{array}{c}10.62 \pm \\
6.362\end{array}$ & $\begin{array}{c}17.01 \pm \\
13.09\end{array}$ & $\begin{array}{c}29.83 \pm \\
7.324\end{array}$ & $\begin{array}{c}116.83 \pm \\
27.63\end{array}$ & ${ }^{\star} 4$ \\
\hline
\end{tabular}

Two-way ANOVA with diagnosis (HC and BD) and sample name (young and old men and women) was used for evaluating statistical significance.

Although antidepressants are used widely in clinical practice, efficacy is not well known and risk of inducing manic switches is concerned [18].

So far it is said that there was no evidence of antidepressant efficacy relative to placebo [18]. As to affective switches antidepressants are not more likely to cause treatment-emergent affective switches than placebo [19].

We have recently shown that plasma levels of 5-HT and 5-HIAA were higher in patients of MMD than HC possibly due to use of reuptake inhibitors such as SSRI or SNRI [20]. In the present research we report that plasma levels of 5-HT were also higher in patients of BD than HC. The mixed results were obtained about plasma levels of 5-HIAA, those oy young women being higher in HC than BD and those of those of old women higher in patients of BD than HC.

Lithium salts used for the treatments of BD induced significant increased plasma levels of 5-HT and 5-HIAA without affecting 5-HT in platelets [21].

We think that increased plasma levels of 5-HIAA in patients of MMD may be due to increased activity of MAO [20]. Using rats, it was shown that plasma levels of 5-HT increased significantly after injection of 5-HT reuptake inhibitors [22].

Determining medication free patients of $\mathrm{MD}$, no changes were found in 5-HT reuptake parameters [23].

In suicide attempters of BD II, significant lower levels of platelet serotonin measured by plasma 5-HT levels were shown [24], which suggest that platelet serotonin may be important biomarker of suicide risk assessment. These patients were drug free.

From these results it appears that plasma levels of 5-HT of BDII patients are lower in drug free situations and higher in use of 5-HT reuptake inhibitors.

Since many kinds of drugs are used for the treatments of BDII, I just mention of lithium because lithium was shown to increase plasma levels of 5-HT [16]. Although lithium has been used for patients of BD for almost 40 years. Several studies have evaluated lithium as prophylactic treatment for BDII with mostly positive findings [3, 25-27]. 


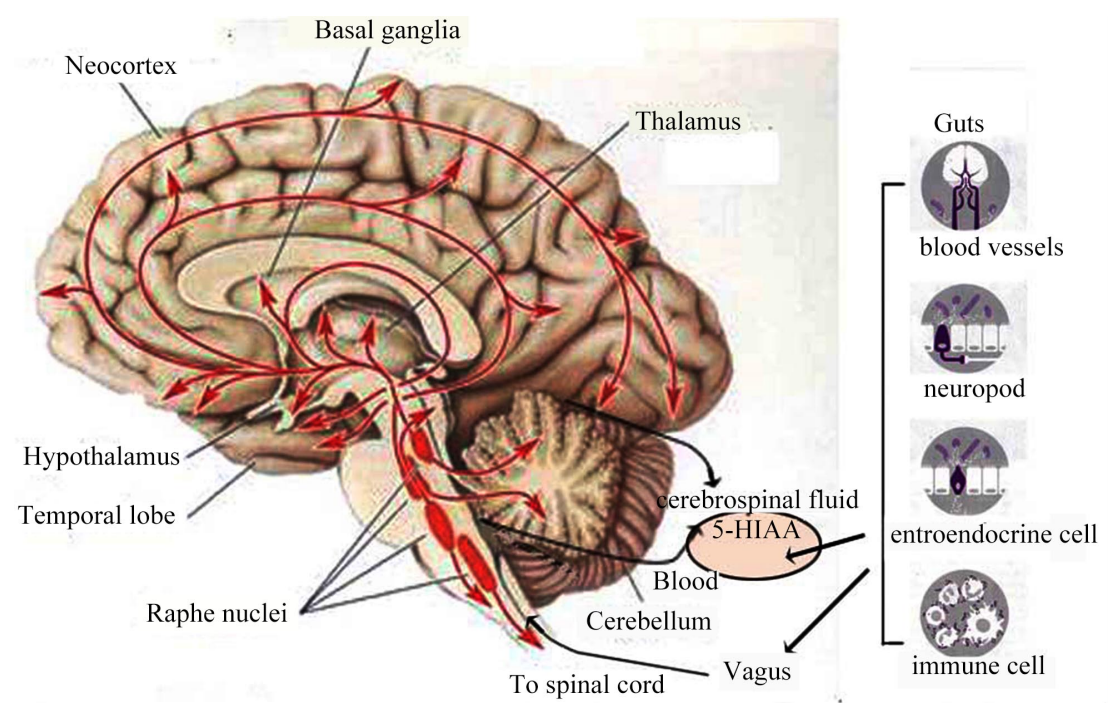

Figure 5. Serotonergic nerve in the brain and cerebrospinal fluid.

Finally, we would like to comment on 5-HT and 5-HIAA levels in patients of depression.

Low levels of 5-HIAA were reported in the cerebrospinal fluid (CSF) of depressive persons who tried suicide [28-30]. Strangely, higher 5-HIAA levels were shown in the raphe nuclei but no differences in the frontal cortex of patients of suicides [31] In other studies of depressed suicide victims increased 5-HIAA levels in the hippocampus [32] and amygdala [33] but no difference in 5-HT in the cortex and amygdala [33]. On the other hand drug-free nonviolent suicide victims had lower 5-HT and 5-HIAA [33].

Figure 5 shows serotonergic nerve in the brain. The nerve bodies of 5-HT nerves are located in raphe nuclei in the brain stem. 5-HIAA flows into the cerebrospinal fluid, finally to the blood.

These results may indicate that there are still conflicting results of 5-HT and 5-HIAA levels in the brain of depressed patients. [34].

As to 5-HT transporter 5-HT transporter binding was lower in the suicide victims in most brain areas

These results may suggest that lower plasma 5-HT levels in patients of depression may be due to use of reuptake inhibitors and lower transporter binding.

So we need more data of plasma levels of 5-HT and 5-HIAA in patients of MMD and BD and such levels of suicide victims.

Finally we must call your attention to roles of microbiota in producing 5-HT and their influences on depression. Evidence suggests that the gut microbiota play a key role in modulating depression [35]. Recent studies show that patients with depression show significantly lower number $\mathrm{s}$ of Bifidobacterium and Lactobacillus compared with control subjects [36]. It is suggested that 5-HT is produced by gut microbes or enteroendocrine cells stimulated by microbes. [37]. These results may suggest that the origins of 5-HT in the blood is gut microbiota. If so, we must investigate roles of gut microbiota in the production of 5-HT to the blood.

\section{CONCLUSION}

Lower plasma 5-HT levels in patients of depression may be due to use of reuptake inhibitors and lower transporter binding. We also suggest that tryptophan metabolites such as 5-HT, 5-HIAA, and KYN in plasma may be produced by gut microbiota and gut endocrine cells.

\section{CONFLICTS OF INTEREST}

The authors declare no conflicts of interest regarding the publication of this paper. 


\section{REFERENCES}

1. Baldessarini, R.J., Pérez, J., Salvatore, P., Trede, K. and Maggini, C. (2015) History of Bipolar Manic-Depressive Disorder. In: Yildiz, A., Ruiz, P., Nemeroff, C.B. and York, N., Eds., The Bipolar Book. History, Neurobiology, and Treatment, Oxford University Press, New York, 3-20. https://doi.org/10.1093/med/9780199300532.003.0001

2. Trede, K., Salvatore, P., Baethge, C., Gerhard, A., Maggini, C. and Baldessarini, R.J. (2005) Manic-Depressive Illness: Evolution in Kraepelins Textbook, 18831926. Harvard Review of Psychiatry, 13, 155-178. https://doi.org/10.1080/10673220500174833

3. Dunner, D.L., Stallone, F. and Fieve, R.R. (1976) Lithium Carbonate and Affective Disorders. V: A Double-Blind Study of Prophylaxis of Depression in Bipolar Illness. Archives of General Psychiatry, 33, 117-120. https://doi.org/10.1001/archpsyc.1976.01770010073014

4. Matsuoka, K., Kato, K., Takao, T., Ogawa, M., Ishii, Y., Shimizu, F., Masuda, J. and Takada, A. (2016) Concentrations of Various Tryptophan Metabolites Increase in Patients of Diabetes Mellitus Compared to Healthy Aged Male Adults. Diabetology International, 8, 69-72. https://doi.org/10.1007/s13340-016-0282-y

5. Takada, A., Shimizu, F. and Masuda, J. (2018) Measurement of Plasma Tryptophan Metabolites: Clinical and Experimental Application for Depression and Stress States Assessment. In: Melatonin-Molecular Biology, Clinical and Pharmaceutical Approaches, IntechOpen, London. https://doi.org/10.5772/intechopen.78560

6. Shimizu, F., Ishii, Y., Ogawa, M., Takao, T., Matsuoka, K., Kato, K. and Takada, A. (2018) Plasma Levels of Tryptophan Metabolites in Healthy Young and Old Men and Women, and Patients of Type 2 Diabetes Mellitus (T2DM). Obesity: Open Access, 4, 1-9. https://doi.org/10.16966/2380-5528.138

7. Takada, A., Shimizu, F. and Masuda, J. (2019) Plasma Levels of Tryptophan Metabolites in Patients of Type 2 Diabetes Mellitus. In: Watson, R. and Preedy, V., Eds., Bioactive Food as Dietary Interventions for Diabetes, 2nd Edition, Academic Press, Cambridge, 265-276. https://doi.org/10.1016/B978-0-12-813822-9.00017-5

8. Tomioka, H., Masuda, J., Takada, A. and Iwanami, A. (2020) Comparison Age and Gender Differences of Tryptophan Metabolites in Patients of Major Monopolar and Bipolar Depression. Foods and Nutrition Science, 11, 172-185. https://doi.org/10.4236/fns.2020.113013

9. Tomioka, H., Masuda, J., Takada, A. and Iwanami, A. (2020) Differences of Plasma Levels of Tryptophan, Serotonin, 5-Hydroxyindole Acetic Acid, and Kynurenine between Healthy People and Patients of Major Monopolar Depression at Various Age and Gender. Foods and Nutrition Science, 11, 431-441.

10. American Psychiatric Association (2013) Diagnostic and Statistical Manual of Mental Disorders 5th Edition (DSM-5). APA, Washington DC. https://doi.org/10.1176/appi.books.9780890425596

11. Guy, W. (1976) Clinical Global Impressions ECDEU Assessment Manual for Psychopharmacology, Revised (DHEW Publ. No. ADM 76-338). National Institute of Mental Health, Rockville, 218-222. https://doi.org/10.1037/e591322011-001

12. Zung, W.W.K. (1965) A Self-Rating Depression Scale. Archives of General Psychiatry, 12, 63-70. https://doi.org/10.1001/archpsyc.1965.01720310065008

13. Hamilton, M. (1960) A Rating Scale for Depression. Journal of Neurology, Neurosurgery and Psychiatry, 23, 56-62. https://doi.org/10.1136/jnnp.23.1.56

14. Mantere, O., Suominen, K., Valtonen, H.M., et al. (2008) Differences in Outcome of DSM-IV Bipolar I and II Disorders. Bipolar Disorders, 10, 413-425. https://doi.org/10.1111/j.1399-5618.2007.00502.x

15. Maina, G., Albert, U., Bellodi, L., et al. (2007) Health-Related Quality of Life in Euthymic Bipolar Disorder Patients: Differences between Bipolar I and II Subtypes. Journal of Clinical Psychiatry, 68, 207-212. https://doi.org/10.4088/JCP.v68n0205

16. Angst, J., Gamma, A., Benazzi, F., Ajdacic, V., Eich, D. and Rossler, W. (2003) Toward a Re-Definition of 
Subthreshold Bipolarity: Epidemiology and Proposed Criteria for Bipolar-II, Minor Bipolar Disorders and Hypomania. Journal of Affective Disorders, 73, 133-146. https://doi.org/10.1016/S0165-0327(02)00322-1

17. Swartz, H.A. and Thase, M.E. (2011) Pharmacotherapy for the Treatment of Acute Bipolar II Depression: Current Evidence. Journal of Clinical Psychiatry, 72, 356-366. https://doi.org/10.4088/JCP.09r05192gre

18. Salvi, V., Fagiolini, A., Swartz, H.A., Maina, G. and Frank, E. (2008) The Use of Antidepressants in Bipolar Disorder. Journal of Clinical Psychiatry, 69, 1307-1318. https://doi.org/10.4088/JCP.v69n0816

19. Sachs, G.S., Nierenberg, A.A., Calabrese, J.R., et al. (2007) Effectiveness of Adjunctive Antidepressant Treatment for Bipolar Depression. New England Journal of Medicine, 356, 1711-1722. https://doi.org/10.1056/NEJMoa064135

20. Tomioka, H., Masuda, J., Takada, A. and Iwanami, A. (2020) Differences of Plasma Levels of Tryptophan, Serotonin, 5-Hydroxyindole Acetic Acid, and Kynurenine between Healthy People and Patients of Major Monopolar Depression at Various Age and Gender. Food and Nutrition Sciences, 11, 431-441.

21. Artigas, F., Sarrias, M.J., Martínez, E., Gelpí, E., Alvarez, E. and Udina, C. (1989) Increased Plasma Free Serotonin But Unchanged Platelet Serotonin in Bipolar Patients Treated Chronically with Lithium. Psychopharmacology (Berl.), 99, 328-332. https://doi.org/10.1007/BF00445552

22. Ortiz, J. and Artigas, F. (1992) Effects of Monoamine Uptake Inhibitors on Extracellular and Platelet 5-Hydroxytryptamine in Rat Blood: Different Effects of Clomipramine and Fluoxetine. British Journal of Pharmacology, 105, 941-946. https://doi.org/10.1111/j.1476-5381.1992.tb09082.x

23. Hrdina, P.D., Bakish, D., Chudzik, J., Ravindran, A. and Lapierre, Y.D. (1995) Serotonergic Markers in Platelets of Patients with Major Depression: Upregulation of 5-HT2 Receptors. Journal of Psychiatry \& Neuroscience, 20, 11-19.

24. Giurgiuca, A., Schipor, S., Caragheorgheopol, A., Crasan, A., Postolache, E., Tudose, C., Prelipceanu, D. and Cozman, D. (2016) Platelet Serotonin as Biomarker for Assessing Suicidal Behaviour in Patients with Bipolar I Disorder. Acta Endocrinologica (Bucharest), 12, 275-281. https://doi.org/10.4183/aeb.2016.275

25. Fieve, R.R., Kumbaraci, T. and Dunner, D.L. (1976) Lithium Prophylaxis of Depression in Bipolar I, Bipolar II, and Unipolar Patients. American Journal of Psychiatry, 133, 925-929. https://doi.org/10.1176/ajp.133.8.925

26. Kane, J.M., et al. (1982) Lithium Carbonate and Imipramine in the Prophylaxis of Unipolar and Bipolar II Illness: A Prospective, Placebo-Controlled Comparison. Archives of General Psychiatry, 39, 1065-1069. https://doi.org/10.1001/archpsyc.1982.04290090053011

27. Tondo, L., Baldessarini, R.J., Hennen, J. and Floris, G. (1998) Lithium Maintenance Treatment of Depression and Mania in Bipolar I and Bipolar II Disorders. American Journal of Psychiatry, 155, 638-645. https://doi.org/10.1176/ajp.155.5.638

28. Asberg, M., Träskman, L. and Thoren, P. (1976) 5-HIAA in the Cerebrospinal Fluid. A Biochemical Suicide Predictor? Archives of General Psychiatry, 33, 1193-1197. https://doi.org/10.1001/archpsyc.1976.01770100055005

29. Träskman, L., Asberg, M., Bertilsson, L. and Sjöstrand, L. (1981) Monoamine Metabolites in CSF and Suicidal Behavior. Archives of General Psychiatry, 38, 631-636. https://doi.org/10.1001/archpsyc.1981.01780310031002

30. Jokinen, J., Nordström, A.L. and Nordström, P. (2009) CSF 5-HIAA and DST Non-Suppression: Orthogonal Biologic Risk Factors for Suicide in Male Mood Disorder in Patients. Psychiatry Research, 165, 96-102. https://doi.org/10.1016/j.psychres.2007.10.007

31. Bach, H., Huang, Y.Y., Underwood, M.D., Dwork, A.J., Mann, J.J. and Arango, V. (2014) Elevated Serotonin and 5-HIAA in the Brainstem and Lower Serotonin Turnover in the Prefrontal Cortex of Suicides. Synapse, 68, 127-130. https://doi.org/10.1002/syn.21695 
32. Owen, F., Chambers, D.R., Cooper, S.J., Crow, T.J., Johnson, J.A., Lofthouse, R. and Poulter, M. (1986) Serotonergic Mechanisms in Brains of Suicide Victims. Brain Research, 362, 185-188.

https://doi.org/10.1016/0006-8993(86)91415-0

33. Cheetham, S.C., Crompton, M.R., Czudek, C., Horton, R.W., Katona, C.L. and Reynolds, G.P. (1989) Serotonin Concentrations and Turnover in Brains of Depressed Suicides. Brain Research, 502, 332-340. https://doi.org/10.1016/0006-8993(89)90629-X

34. Arango, V., Underwood, M.D., Gubbi, A.V. and Mann, J.J. (1995) Localized Alterations in Pre- and Postsynaptic Serotonin Binding Sites in the Ventrolateral Prefrontal Cortex of Suicide Victims. Brain Research, 688, 121-133. https://doi.org/10.1016/0006-8993(95)00523-S

35. Dinan, T.G. and Cryan, J.F. (2013) Melancholic Microbes: A Link between Gut Microbiota and Depression? Neurogastroenterology \& Motility, 25, 713-719. https://doi.org/10.1111/nmo.12198

36. Aizawa, E., Tsuji, H., Asahara, T., Takahashi, T., Teraishi, T., Yoshida, S., Ota, M., Koga, N., Hattori, K. and Kunugi, H. (2016) Possible Association of Bifidobacterium and Lactobacillus in the Gut Microbiota of Patients with Major Depressive Disorder. Journal of Affective Disorders, 202, 254-257. https://doi.org/10.1016/j.jad.2016.05.038

37. Pennisi, E. (2020) Meet the Psychobiome. Science, 368, 570-573. https://doi.org/10.1126/science.368.6491.570

\section{ABBREVIATION}

Tryptophan (TRP), serotonin (5-HT), 5-hydroxyindole acetic acid (5-HIAA), indole-3-acetic acid (IAA), kynurenine (KYN), selective serotonin uptake inhibitor (SSRI), serotonin epinephrine reuptake inhibitor (SNRI), clinical global impression-severity scale (CGI-s), self-rating depression scale (SDS), Hamilton depression rating scale (HDRS). 